\author{
JOANNA FURMAŃSKA, TERESA RZEPA, \\ MARIA PIETRZAK-NOWACKA, DOROTA KOZIARSKA
}

$\stackrel{\odot}{\|}$

\title{
PSYCHOSPOKECZNE UWARUNKOWANIA OCENY ZNACZENIA WŁASNEJ CHOROBY PRZEZ OSOBY PRZEWLEKLE CHORE
}

\begin{abstract}
Joanna Furmańska, Teresa Rzepa, Maria Pietrzak-Nowacka, Dorota Koziarska, Psychospołeczne uwarunkowania oceny znaczenia własnej choroby przez osoby przewlekle chore [Psychosocial determinants of the appraisal of disease significance by patients with a chronic disease] edited by A. Jasielska,

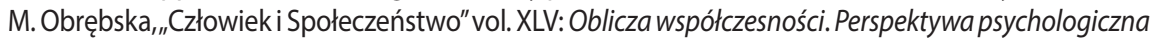
[Faces of modernity. A psychological perspective], Poznań 2018, pp. 245-261, Adam Mickiewicz University. Faculty of Social Sciences Press. ISSN 0239-3271.
\end{abstract}

The literature on the subject identifies chronic disease as a stressor which imposes new adaptive tasks on patients and requires them to change their lifestyle. Therefore, the issues of disease assessment and adaptation to illness, based on individual knowledge of the disease and subjective appraisal of its influence on day-to-day functioning, are becoming increasingly important. In the present article, the appraisal of disease significance is to be understood as a dynamic effect of subjective assessment of one's own life situation due to chronic disease. The aim of the analysis was validation of the relationship between the basic sociodemographic factors and the appraisal of the significance of a chronic disease among patients with RRMS and diabetes type 2 , as well as verification whether these two diseases show any differences in terms of appraisal of their significance in opinion of the patients. In order to verify the hypotheses, The Disease-Related Appraisals Scale, and original scorecard designed to obtain sociodemographic data were used. The analysis was conducted on 118 patients with RRMS and 61 patients with diabetes type 2 . The results show a statistically significant relationship between education level and the appraisal of disease significance considered as benefit and injustice among the two groups of patients. Additionally, in the group of patients with diabetes type 2, the aforementioned relationship was also found for appraisal of disease significance considered as a threat. Moreover, it was found that the analysed groups show significant differences in terms of recognition of the disease as an obstacle/loss. Diagnostic assessment of disease significance sets the direction and methods of therapeutic intervention provided, with the primary aim of improving the quality of life of patients suffering from a chronic disease. 
Joanna Furmańska, Instytut Psychologii Uniwersytetu Szczecińskiego, ul. Krakowska 69, 71-017 Szczecin, e-mail: furmanska-joanna@wp.pl

Teresa Rzepa, Uniwersytet SWPS, Wydział Zamiejscowy w Poznaniu, ul. Gen. Tadeusza Kutrzeby 10, 61-719 Poznań, e-mail: trz@data.pl

Maria Pietrzak-Nowacka, Klinika Nefrologii, Transplantologii i Chorób Wewnętrznych Pomorskiego Uniwersytetu Medycznego, al. Powstańców Wielkopolskich 72, 70-111 Szczecin, e-mail: mariola. nowacka@02.pl

Dorota Koziarska, Katedra i Klinika Neurologii Pomorskiego Uniwersytetu Medycznego, ul. Unii Lubelskiej 1,71-252 Szczecin, e-mail: synaps3@wp.pl

\section{Wprowadzenie}

Choroba przewlekła jest najczęściej rozumiana jak permanentny stresor, który nie tylko skłania chorą osobę do zmiany dotychczasowego stylu życia, lecz również może ją stygmatyzować (Goffman, 2005; Lazarus i Folkman, 1984; Rzepa i Stanišić, 2012). W tym kontekście coraz większej wagi nabiera ocena znaczenia własnej choroby, bazująca na jednostkowej wiedzy oraz na odczuwanych skutkach jej oddziaływania na codzienne funkcjonowanie. Ta struktura poznawcza, określana szerzej jako obraz własnej choroby (Heszen-Klemens, 1979), zawiera informacje o jej genezie, przebiegu, leczeniu i rokowaniach. Ponadto poszczególne elementy obrazu choroby mogą mieć wartość stygmatyzującą, gdyż często są nasycone tak negatywnymi emocjami, jak lęk, obawa, wstyd czy poczucie winy, związanymi przeważnie z widocznymi oznakami choroby i/lub z przyczynami zachorowania leżącymi ewidentnie po stronie pacjenta (Goffman, 2005; Rzepa, Żaba i Jakubowicz, 2014). Choroba może zatem jawić się jako coś zagrażającego i przerażającego albo jako coś mało istotnego, traktowanego jak kolejny problem do rozwiązania czy okazja do ucieczki od poważniejszych kłopotów życiowych.

W nawiązaniu do fenomenologiczno-poznawczego ujęcia stresu (Lazarus, 1966) Zbigniew J. Lipowski (1970) utworzył osiem kategorii znaczeniowych służących ocenie własnej choroby, do których należą: wyzwanie, wróg, kara, słabość, ulga, korzyść (strategia), strata i wartość. Każda z tych kategorii wzbudza określone emocje, nadające chorobie osobiste znaczenie i warunkujące sposób adaptacji do niej, ponieważ uruchamiają odpowiednią motywację i strategie radzenia sobie z chorobą (Keltikangas-Jarvinen, 1986; Schussler, 1992). W odwołaniu do tej koncepcji Konrad Janowski ze współpracownikami (2009) wyróżnili siedem kategorii oceny znaczenia własnej choroby, 
tj.: zagrożenie, korzyść, przeszkodę/stratę, wyzwanie, krzywdę, wartość, znaczenie, i opracowali odpowiednie narzędzie pomiarowe.

Ocena znaczenia własnej choroby jest więc skojarzona z jej poznawczym odzwierciedleniem, z przeżywaniem emocjonalnym oraz ze zmianami funkcjonowania w otoczeniu społecznym. W niniejszym artykule ocena znaczenia choroby jest rozumiana jako dynamiczny efekt subiektywnej oceny własnej sytuacji życiowej uwarunkowanej przewlekłą chorobą (Chojnacka-Szawłowska, 2012). Dotychczasowe ustalenia empiryczne przekonują, że na przebieg leczenia i adaptację do chorób przewlekłych wpływają między innymi czynniki socjodemograficzne oraz zasoby osobiste wzmacniane bądź uszczuplane zależnie od oceny znaczenia choroby (Majda i Józefowska, 2009; Michałowska-Wieczorek, 2006; Rzepa, Żaba, Jakubowicz i Szramka-Pawlak, 2013; Szramka-Pawlak i in., 2013; Ziarko, 2014). Przegląd piśmiennictwa skłania do zwrócenia uwagi na te czynniki, zwłaszcza że - chociaż choroba jest jedna, objawy i stan kliniczny podobne - każdy człowiek choruje inaczej (Sak, 2013; Toombs, 2003).

Dlatego też w odwołaniu do dotychczasowych ustaleń empirycznych, własnych obserwacji klinicznych, rozmów z pacjentami i ich rodzinami oraz z personelem medycznym postanowiono w badaniu własnym zweryfikować zależności między wybranymi czynnikami socjodemograficznymi (płeć, wykształcenie i stan cywilny) a oceną znaczenia porównywanych chorób przewlekłych (stwardnienie rozsiane i cukrzyca typu 2).

\section{Charakterystyka wybranych chorób przewlekłych}

Choroba przewlekła to przypadłość o długotrwałym charakterze i niepewnym rokowaniu, związana z dysfunkcjami organizmu i niepełnosprawnością wymagającą specjalistycznej rehabilitacji i opieki (Koligat i in., 2012; Ziarko, 2014). Obserwacja osób zmagających się z tą samą chorobą przewlekłą przekonuje, że każdorazowo jest to doświadczenie unikatowe $\mathrm{i}$ indywidualne. U jednych pacjentów choroba niczego nie zmienia, u innych wywołuje tak duże zmiany, że osoby bliskie spoglądają na nich jak na „obcych”, a u jeszcze innych prowadzi do ujawnienia wyjątkowo szlachetnych cech. Tak odmienne reakcje w obliczu choroby przewlekłej wskazują na indywidualne różnice zarówno w ocenie jej znaczenia, jak i w radzeniu sobie ze stresem spowodowanym chorobą (Dolińska-Zygmunt, 2001). Dlatego do badania dobrano pacjentów zmagających się z dwiema różnymi 
chorobami przewlekłymi. Chodzi o (1) rzutowo-remisyjną postać stwardnienia rozsianego (SMRR), chorobę o nieznanej etiologii, rozwijającą się rzutami, nieuleczalną i w znacznym stopniu upośledzającą i stygmatyzującą funkcjonowanie psychospołeczne i zawodowe, oraz o (2) cukrzycę typu 2, chorobę o znanej etiologii, rozwijającą się stopniowo, uleczalną i w nieznaczny sposób modyfikującą i stygmatyzującą psychospołeczne funkcjonowanie osób chorych.

Stwardnienie rozsiane (sclerosis multiplex, SM) jest przewlekłą chorobą demielinizacyjną ośrodkowego układu nerwowego, o niejasnej etiologii (Wender i Liberski, 2013). Pierwsze objawy choroby (częściej u kobiet) pojawiają się między 20. a 40. rokiem życia, m.in. jako zaburzenia czucia w kończynach i w obrębie twarzy, zaburzenia widzenia, niedowłady, zaburzenia chodu i równowagi, nerwobóle (Maciejak i Wawrzyniak, 2013). Do przewlekłych objawów SM zalicza się zaburzenia funkcji rdzenia kręgowego, w tym zaburzenia czucia i niedowład piramidowy. Wraz z postępem choroby pojawiają się zaburzenia czynności pęcherza moczowego i zwieraczy odbytu oraz zaburzenia seksualne. Objawem dominującym jest zmęczenie nasilające się pod wpływem stresu, spadku nastroju, przedłużonej aktywności ruchowej (Zaborski, 2010).

Ze względu na to, że SM pojawia się zazwyczaj w okresie najważniejszych wydarzeń życiowych, jak ukończenie edukacji, podjęcie pracy, rozwój kariery zawodowej i założenie rodziny, informacja o nieuleczalnej i postępującej chorobie przewlekłej stanowi wyjątkowo negatywne i stygmatyzujące doświadczenie. Dotychczasowe życie ulega radykalnej zmianie w wymiarze osobistym, rodzinnym i zawodowym.

Cukrzyca typu 2 (diabetes mellitus typi 2 ) jest przewlekłą chorobą metaboliczną, która charakteryzuje się wysokim stężeniem glukozy we krwi, a także opornością na insulinę i jej względnym niedoborem. Do podstawowych czynników ryzyka zalicza się predyspozycje genetyczne, a także starszy wiek, nadwagę i brak aktywności fizycznej. U większości pacjentów choroba pozostaje nierozpoznana przez wiele lat i rozwija się powoli. Klasyczne objawy cukrzycy typu 2 to osłabienie, zwiększone oddawanie moczu, nadmierne pragnienie, a także utrata ostrości wzroku, bóle nóg, świąd skóry. Do przewlekłych powikłań cukrzycy należą m.in.: retinopatia i neuropatia cukrzycowa czy zespół stopy cukrzycowej (Czupryniak i Strojek, 2016; Moczulski, 2010).

Jednym z podstawowych czynników prewencji oraz leczenia cukrzycy typu 2 są interwencje behawioralne, oparte na zmianie trybu życia, samokontroli, zmniejszeniu kaloryczności posiłków i zwiększeniu aktywności fizycznej (Klupa, 2010). Systematyczne i zaangażowane wypełnianie tego 
typu zaleceń prowadzi do zahamowania postępu choroby i zmniejsza jej stygmatyzujący aspekt.

\section{Cel, metody i procedura badawcza}

Główny cel badawczy polegał na zweryfikowaniu zależności między wybranymi czynnikami socjodemograficznymi (płeć, wykształcenie i stan cywilny) a oceną znaczenia porównywanych chorób przewlekłych. W związku z tak określonym celem badawczym sformułowano następujące pytania: Czy zachodzą zależności między płcią, wykształceniem i stanem cywilnym a oceną znaczenia własnej choroby wśród pacjentów z SMRR oraz z cukrzycą typu 2? Czy obie choroby różnią się ze względu na ocenę ich znaczenia wydaną przez pacjentów? Hipotetycznie założono, że wymienione zależności zachodzą oraz że obie choroby różnią się ze względu na ocenę ich znaczenia.

Do identyfikacji oceny znaczenia choroby posłużyła Skala Oceny Własnej Choroby (SOWC) (Janowski, Steuden, Kuryłowicz i NieśpiałowskaSteuden, 2009), która składa się z 47 twierdzeń. SOWC pozwala na ocenę własnej choroby w następujących kategoriach: Zagrożenie (8 pozycji), Korzyść (7 pozycji), Przeszkoda/Strata (8 pozycji), Wyzwanie (6 pozycji), Krzywda (7 pozycji), Wartość (6 pozycji).

Choroba utożsamiana z Zagrożeniem jest traktowana jako destabilizujące wydarzenie życiowe, które zakłóca dotychczasowy stan bezpieczeństwa i równowagi, budzi lęk, narusza plany na przyszłość i wywołuje niepewność co do dalszego biegu życia. Choroba oceniana jako Korzyść wiąże się z osiąganiem wtórnych zysków w postaci zwolnienia z obowiązków i odpowiedzialności, z doznawaniem współczucia, zainteresowania i wsparcia, a nawet z okazją do pozyskiwania korzyści materialnych czy ucieczki przed kłopotami. Przeszkoda/Strata oznacza ocenę choroby w kategoriach koniecznych ograniczeń dotyczących aktualnego funkcjonowania oraz rezygnacji z planów i marzeń. Choroba to stygmatyzujące utrudnienie, które negatywnie wpływa na życie rodzinne i zawodowe, na kontakty z innymi i niezależność osobistą. Kategoria Wyzwanie wiąże się z oceną choroby jako trudnej sytuacji życiowej - przeszkody, z którą należy walczyć i którą trzeba pokonać, mobilizując swe siły i zasoby osobiste. Choroba ujmowana jako Krzywda oznacza postrzeganie jej w kategoriach nieszczęścia, niezasłużonej i niesprawiedliwej kary. Kategoria Wartość wyznacza ocenę choroby jako posiadającej głębszy sens, mimo że jest on trudny do zrozumienia i zaakceptowania. 
Poza wyróżnionymi kategoriami oceny własnej choroby SOWC zawiera także skalę kontrolną (Znaczenie), która pozwala na pomiar negatywnego znaczenia przypisywanego własnej chorobie (Janowski i in., 2009).

W przeprowadzonym badaniu rzetelność SOWC okazała się odpowiednia, ponieważ $\alpha$ Cronbacha dla poszczególnych skal wyniosła: zagrożenie-0,88; korzyść - 0,62; przeszkoda - 0,84; wyzwanie - 0,62; krzywda - 0,83; wartość - 0,75; skala kontrolna (znaczenie nadawane własnej chorobie) - 0,68.

Dane socjodemograficzne pozyskano za pomocą metryczki zamieszczonej na końcu kwestionariusza SOWC.

Badanie przeprowadzono w latach 2016-2017 za zgodą Komisji Bioetycznej Uniwersytetu Szczecińskiego (KB 1/2016). Udział w badaniu był dobrowolny. Uczestniczyli w nim pacjenci leczący się w Klinice Neurologii SPSK1 PUM w Szczecinie, w Centrum Rehabilitacji SM w Bornym Sulinowie oraz w Poradni Diabetologicznej SPSK2 w Szczecinie.

Zbadano 118 osób chorych na SMRR. Średnia wieku wynosiła 45,88 lat ( $S D=11,277)$. Kobiety stanowiły 68,6\% (stosunek $2: 1$ ), co wynika ze specyfiki rozkładu płci wśród osób chorujących na SMRR. Większość badanych $(88,1 \%)$ pozostawała w związku małżeńskim lub partnerskim. Wykształcenia podstawowego nie odnotowano, wykształcenie zawodowe miało 16,9\% pacjentów, średnie - 45,8\%, licencjackie - 1,7\%, wyższe - 35,6\%.

Do drugiej grupy zakwalifikowano 61 osób z cukrzycą typu 2. Średnia wieku wyniosła 67,61 lat ( $S D=8,251)$. Kobiety stanowiły 50,8\% grupy. W związku małżeńskim lub partnerskim pozostawało 75,4\% badanych. Rozkład wykształcenia był następujący: podstawowe - 16,4\%, zawodowe - 29,5\%, średnie - 27,9\%, licencjackie - 1,6\%, wyższe - 24,6\%.

\section{Wyniki}

Analizę wyników rozpoczęto od sprawdzenia zależności między czynnikami socjodemograficznymi a oceną znaczenia choroby przez pacjentów z SMRR i z cukrzycą typu 2. W odniesieniu do pacjentów z SMRR ustalono, że wykształcenie jest powiązane z oceną znaczenia własnej choroby jako korzyści i krzywdy $(p<0,05)$. Osoby z wykształceniem licencjackim i wyższym w mniejszym stopniu traktują chorobę jako nieszczęście stanowiące niezasłużoną karę oraz jako powód do pozyskiwania wtórnych zysków aniżeli osoby z wykształceniem zawodowym i średnim. Ponadto stwierdzono brak zależności między płcią i stanem cywilnym (pozostawaniem w związku) a oceną znaczenia własnej choroby (tabela 1). 
Tabela 1. Płeć, wykształcenie, stan cywilny a ocena znaczenia choroby wśród osób z SMRR ( $\mathrm{N}$ = 118)

\begin{tabular}{|c|c|c|c|c|c|c|}
\hline $\begin{array}{c}\text { Choroba } \\
\text { oceniana } \\
\text { jako: }\end{array}$ & Parametr & $B$ & $\begin{array}{c}\text { Błąd } \\
\text { standar- } \\
\text { dowy }\end{array}$ & $\beta$ & $\begin{array}{c}\text { Podsumowanie } \\
\text { modelu }\end{array}$ & $\begin{array}{l}\text { Skorygo- } \\
\text { wane } \mathrm{R}^{2}\end{array}$ \\
\hline \multirow{4}{*}{ Zagrożenie } & stała & 22,621 & 2,458 & & $\begin{array}{c}F(3 ; 114)= \\
0,969 ; p>0,05\end{array}$ & 0,001 \\
\hline & płeć & 1,761 & 1,763 & 0,097 & & \\
\hline & stan cywilny & 3,197 & 2,089 & 0,146 & & \\
\hline & wykształcenie & $-0,408$ & 1,668 & $-0,024$ & & \\
\hline \multirow{4}{*}{ Korzyść } & stała & 18,764 & 1,356 & & $\begin{array}{c}F(3 ; 114)= \\
3,437 ; p<0,05\end{array}$ & 0,059 \\
\hline & płeć & $-1,662$ & 0,973 & $-0,161$ & & \\
\hline & stan cywilny & $-2,007$ & 1,153 & $-0,161$ & & \\
\hline & wykształcenie & $-1,862$ & 0,920 & $-0,189 *$ & & \\
\hline \multirow{4}{*}{ Przeszkoda } & stała & 23,927 & 2,303 & & $\begin{array}{c}F(3 ; 114)= \\
0,751 ; p>0,05\end{array}$ & 0,006 \\
\hline & płeć & $-0,474$ & 1,651 & $-0,028$ & & \\
\hline & stan cywilny & $-0,497$ & 1,957 & $-0,024$ & & \\
\hline & wykształcenie & $-2,134$ & 1,563 & $-0,132$ & & \\
\hline \multirow{4}{*}{ Wyzwanie } & stała & 23,653 & 1,221 & & $\begin{array}{c}F(3 ; 114)= \\
1,078 ; p>0,05\end{array}$ & 0,002 \\
\hline & płeć & $-1,514$ & 0,876 & $-0,168$ & & \\
\hline & stan cywilny & $-0,120$ & 1,037 & $-0,011$ & & \\
\hline & wykształcenie & 0,006 & 0,828 & 0,001 & & \\
\hline \multirow{4}{*}{ Krzywda } & stała & 19,452 & 1,959 & & $\begin{array}{c}F(3 ; 114)= \\
2,985 ; p<0,05\end{array}$ & 0,048 \\
\hline & płeć & $-1,208$ & 1,405 & $-0,082$ & & \\
\hline & stan cywilny & $-0,395$ & 1,665 & $-0,022$ & & \\
\hline & wykształcenie & $-3,412$ & 1,329 & $-0,241^{*}$ & & \\
\hline \multirow{4}{*}{ Wartość } & stała & 17,952 & 1,575 & & $\begin{array}{c}F(3 ; 114)= \\
1,125 ; p>0,05\end{array}$ & 0,003 \\
\hline & płeć & $-0,093$ & 1,129 & $-0,008$ & & \\
\hline & stan cywilny & $-0,896$ & 1,338 & $-0,064$ & & \\
\hline & wykształcenie & $-1,838$ & 1,069 & $-0,165$ & & \\
\hline \multirow{4}{*}{ Znaczenie } & stała & 14,704 & 1,345 & & $\begin{array}{c}F(3 ; 114)= \\
1,045 ; p>0,05\end{array}$ & 0,001 \\
\hline & płeć & 0,386 & 0,964 & 0,039 & & \\
\hline & stan cywilny & 1,733 & 1,143 & 0,144 & & \\
\hline & wykształcenie & 0,899 & 0,912 & 0,095 & & \\
\hline
\end{tabular}

Źródło: opracowanie własne. 
Analiza wyników uzyskanych przez pacjentów z cukrzycą typu 2 (tabela 2) pokazała, że wykształcenie jest powiązane z oceną znaczenia własnej choroby.

Tabela 2. Płeć, wykształcenie i stan cywilny a ocena znaczenia choroby wśród osób z cukrzycą typu $2(\mathrm{~N}=61)$

\begin{tabular}{|c|c|c|c|c|c|c|}
\hline $\begin{array}{c}\text { Choroba } \\
\text { oceniana } \\
\text { jako: }\end{array}$ & Parametr & $B$ & $\begin{array}{c}\text { Błąd } \\
\text { standar- } \\
\text { dowy }\end{array}$ & $\beta$ & $\begin{array}{c}\text { Podsumowanie } \\
\text { modelu }\end{array}$ & $\begin{array}{l}\text { Skorygo- } \\
\text { wane } R 2\end{array}$ \\
\hline \multirow{4}{*}{ Zagrożenie } & stała & 27,792 & 2,806 & & $\begin{array}{c}F(3 ; 57)= \\
4,772 ; p<0,01\end{array}$ & 0,159 \\
\hline & płeć & 3,054 & 2,206 & 0,172 & & \\
\hline & \begin{tabular}{|l|} 
stan cywilny \\
\end{tabular} & $-1,176$ & 2,529 & $-0,057$ & & \\
\hline & wykształcenie & $-7,618$ & 2,423 & $-0,377 * *$ & & \\
\hline \multirow{4}{*}{ Korzyść } & stała & 14,708 & 1,605 & & $\begin{array}{c}F(3 ; 57)= \\
2,435 ; p>0,05 \\
\end{array}$ & 0,067 \\
\hline & płeć & 0,511 & 1,262 & 0,053 & & \\
\hline & \begin{tabular}{|l|} 
stan cywilny \\
\end{tabular} & 0,129 & 1,446 & 0,012 & & \\
\hline & wykształcenie & $-3,558$ & 1,386 & $-0,325^{*}$ & & \\
\hline \multirow{4}{*}{ Przeszkoda } & stała & 19,722 & 2,625 & & $\begin{array}{c}F(3 ; 57)= \\
0,868 ; p>0,05\end{array}$ & 0,007 \\
\hline & płeć & 0,536 & 2,063 & 0,035 & & \\
\hline & stan cywilny & $-0,321$ & 2,365 & $-0,018$ & & \\
\hline & wykształcenie & $-3,433$ & 2,266 & $-0,199$ & & \\
\hline \multirow{4}{*}{ Wyzwanie } & stała & 24,159 & 1,880 & & $\begin{array}{c}F(3 ; 57)= \\
0,894 ; p>0,05 \\
\end{array}$ & 0,005 \\
\hline & płeć & 0,389 & 1,478 & 0,036 & & \\
\hline & \begin{tabular}{|l|} 
stan cywilny \\
\end{tabular} & $-1,850$ & 1,694 & $-0,146$ & & \\
\hline & wykształcenie & $-1,668$ & 1,623 & $-0,135$ & & \\
\hline \multirow{4}{*}{ Krzywda } & stała & 18,992 & 2,305 & & $\begin{array}{c}F(3 ; 57)= \\
5,822 ; p<0,01\end{array}$ & 0,194 \\
\hline & płeć & 1,715 & 1,812 & 0,115 & & \\
\hline & stan cywilny & $-1,515$ & 2,077 & $-0,088$ & & \\
\hline & wykształcenie & $-7,436$ & 1,990 & $-0,439 * * *$ & & \\
\hline \multirow{4}{*}{ Wartość } & stała & 18,056 & 2,059 & & $\begin{array}{c}F(3 ; 57)= \\
0,855 ; p>0,05 \\
\end{array}$ & 0,007 \\
\hline & płeć & $-0,920$ & 1,619 & $-0,077$ & & \\
\hline & \begin{tabular}{|l|} 
stan cywilny \\
\end{tabular} & $-2,957$ & 1,855 & $-0,214$ & & \\
\hline & wykształcenie & $-0,181$ & 1,778 & $-0,013$ & & \\
\hline \multirow{4}{*}{ Znaczenie } & stała & 16,760 & 1,565 & & $\begin{array}{c}F(3 ; 57)= \\
2,224 ; p>0,05\end{array}$ & 0,058 \\
\hline & \begin{tabular}{|l} 
płeć \\
\end{tabular} & 1,785 & 1,230 & 0,191 & & \\
\hline & stan cywilny & $-1,142$ & 1,410 & $-0,105$ & & \\
\hline & wykształcenie & $-2,010$ & 1,351 & $-0,189$ & & \\
\hline
\end{tabular}


Osoby z wykształceniem licencjackim i wyższym w mniejszym stopniu oceniają chorobę jako zagrożenie dla ich funkcjonowania i realizowania zamierzonych planów ( $p<0,01)$ oraz w mniejszym stopniu ujmują ją jako korzyść $(p<0,01)$ i krzywdę $(p<0,001)$ niż osoby z wykształceniem podstawowym, zawodowym i średnim.

Podsumowując, należy stwierdzić, że wykształcenie wykazuje istotny statystycznie związek z oceną znaczenia własnej choroby jako korzyści i krzywdy w odniesieniu do obu grup pacjentów, a w przypadku chorych z cukrzycą typu 2 również jako zagrożenia.

Następnie porównano oceny znaczenia własnej choroby dokonane przez pacjentów należących do obu grup. Ustalono, że oceny obu chorób w kategoriach zagrożenia, krzywdy, korzyści, wyzwania i wartości są podobne wśród chorych na SMRR i cukrzycę typu 2. Chorzy na SMRR statystycznie istotnie $(p<0,01)$ częściej niż chorzy na cukrzycę typu 2 ocenili swoją chorobę jako stygmatyzującą przeszkodę/stratę (tabela 3).

Tabela 3. Ocena znaczenia własnej choroby wśród chorych na SMRR i cukrzycę typu 2

\begin{tabular}{|c|c|c|c|c|c|c|}
\hline $\begin{array}{l}\text { Choroba } \\
\text { oceniana } \\
\text { jako: }\end{array}$ & $\begin{array}{l}\text { Rodzaj } \\
\text { próby }\end{array}$ & $\begin{array}{c}\text { Min } \\
\text { teoretyczne/ } \\
\text { empiryczne }\end{array}$ & $\begin{array}{c}\text { Max } \\
\text { teoretyczne/ } \\
\text { empiryczne }\end{array}$ & M & SD & Wynik testu t-Studenta \\
\hline \multirow{3}{*}{ Zagrożenie } & cała próba & $8 / 8$ & $40 / 40$ & 26,36 & 8,58 & \\
\hline & SMRR & 8 & 40 & 26,31 & 8,427 & $t(177)=0,113 ; p>0,05$ \\
\hline & cukrzycy & 8 & 40 & 26,46 & 8,951 & \\
\hline \multirow{3}{*}{ Korzyść } & cała próba & $7 / 7$ & $35 / 27$ & 14,89 & 4,83 & \\
\hline & SMRR & 7 & 27 & 15,28 & 4,795 & $t(177)=1,512 ; p>0,05$ \\
\hline & cukrzycy & 7 & 25 & 14,13 & 4,860 & \\
\hline \multirow{3}{*}{ Przeszkoda } & cała próba & $8 / 8$ & $40 / 40$ & 21,19 & 7,96 & \\
\hline & SMRR & 8 & 39 & 22,40 & 7,872 & $t(177)=2,883 ; p<0,01^{* *}$ \\
\hline & cukrzycy & 8 & 40 & 18,85 & 7,653 & \\
\hline \multirow{3}{*}{ Wyzwanie } & cała próba & $6 / 6$ & $30 / 30$ & 22,52 & 4,66 & \\
\hline & SMRR & 10 & 30 & 22,52 & 4,191 & $t(177)=0,010 ; p>0,05$ \\
\hline & cukrzycy & 6 & 30 & 22,52 & 5,485 & \\
\hline \multirow{3}{*}{ Krzywda } & cała próba & $7 / 7$ & $35 / 35$ & 16,94 & 7,09 & \\
\hline & SMRR & 7 & 35 & 17,03 & 6,887 & $t(177)=0,228 ; p>0,05$ \\
\hline & cukrzycy & 7 & 32 & 16,77 & 7,511 & \\
\hline \multirow{3}{*}{ Wartość } & cała próba & $6 / 6$ & $30 / 30$ & 16,07 & 5,63 & \\
\hline & SMRR & 6 & 30 & 16,47 & 5,409 & $t(177)=1,304 ; p>0,05$ \\
\hline & cukrzycy & 6 & 30 & 15,31 & 6,002 & \\
\hline
\end{tabular}

Źródło: opracowanie własne. 
W celu pogłębionego porównania ocen znaczenia własnej choroby przez badanych pacjentów przeprowadzono analizę ich względnej ważności metodą dwustopniowego grupowania. Ustalono, że osoby przewlekle chore traktują zgodnie zagrożenie jako najbardziej znaczącą, względnie ważną ocenę własnej choroby (wykres). Największa różnica międzygrupowa dotyczy względnej ważności oceny choroby jako negatywnego wydarzenia życiowego (Znaczenie) przez pacjentów z SMRR. Kolejne różnice dotyczą oceny własnej choroby jako stygmatyzującej przeszkody/straty i krzywdy. Natomiast chorzy na cukrzycę typu 2 przypisują wyższą niż pacjenci z SMRR względną ważność takim ocenom swej choroby, jak korzyść, wyzwanie i wartość, choć należy podkreślić, że te oceny wystąpiły o wiele rzadziej niż pozostałe.

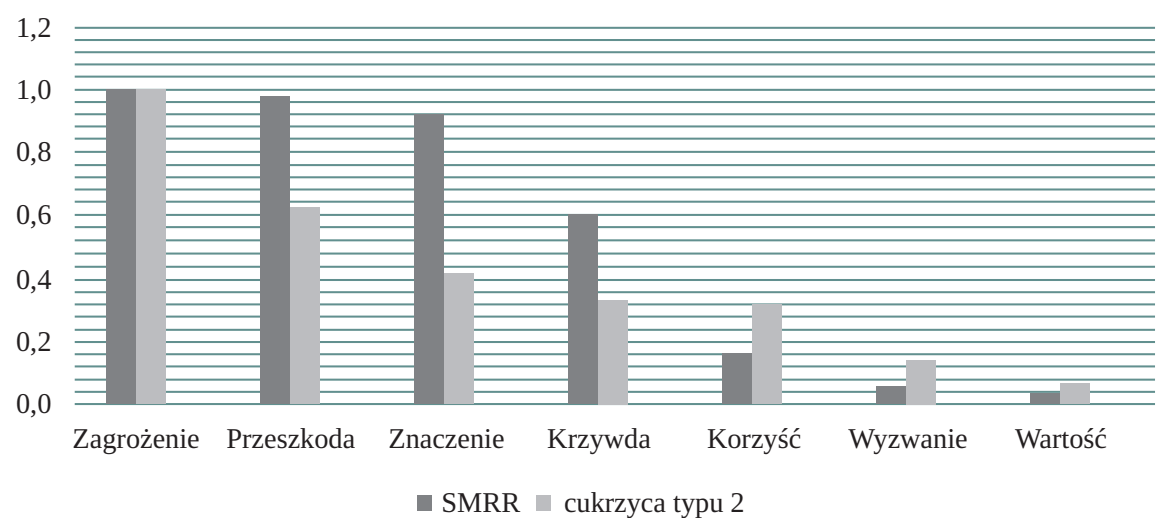

Wykres. Porównanie względnej ważności ocen znaczenia własnej choroby przez pacjentów z SMRR i z cukrzycą typu 2

Źródło: opracowanie własne.

\section{Dyskusja wyników}

Przeprowadzone badanie wskazało na brak związku między płcią i oceną znaczenia obu chorób przewlekłych, co jest zgodne z większością doniesień empirycznych (Brzozowska i Talarska, 2001; Karakiewicz i in., 2010; Kossakowska, 2007). Co prawda, w kilku badaniach wykazano, że płeć różnicuje chorych ze względu na ocenę znaczenia choroby jako krzywdy, korzyści, przeszkody/straty, przy czym tak swą chorobę częściej oceniali mężczyźni (Janowski, 2006; Janowski i in., 2009). Z kolei niektóre ustalenia empiryczne dotyczące SM sugerują, że kobiety są skłonne przypisywać tej chorobie większą siłę destrukcyjną aniżeli mężczyźni zarówno w zakresie 
stygmatyzujących zmian psychofizycznych, jak i utraty motywacji do walki z chorobą (Król, Koziarska, Rzepa, Szcześniak i Nowacki, 2017).

Przegląd dotychczasowych badań dowodzi, że kobiety generalnie zgłaszają więcej symptomów somatycznych, czują się bardziej chore oraz gorzej oceniają swą kondycję zdrowotną niż mężczyźni (Chojnacka-Szawłowska, 2012). Może to być związane z normami społeczno-kulturowymi, które niejako przyzwalają kobietom na większą chorowitość i na otwarte informowanie o swych dolegliwościach. Wyniki Europejskiego Ankietowego Badania Zdrowia (EHIS) jednoznacznie pokazały, że kobiety o wiele częściej niż mężczyźni korzystały z usług medycznych, częściej niż oni zażywały leki, dbały o profilaktykę i prowadziły zdrowy styl życia (Zdrowie..., 2015). Kobieca nadwrażliwość na tle symptomów psychosomatycznych wyjaśnia wyższe niż u mężczyzn poczucie stygmatyzacji spowodowanej przewlekłą chorobą (Schmid-Ott, Jäger, Kuensbeck, Ott i Lamprecht, 1996). Wiąże się ono z wyższym poziomem wstydu i poczucia winy, a więc z dojmującym obciążeniem emocjonalnym (Goffman, 2005; Rzepa, Jakubowicz, Witmanowski i Żaba, 2013). Wśród mężczyzn poczucie stygmatyzacji łączy się przeważnie z obawą o utratę pracy (Böhm i in., 2013; Gupta i Gupta, 1995). Być może dlatego mężczyźni częściej oceniają swoją chorobę jako wyzwanie życiowe, które skłania do mobilizacji sił i podjęcia konkretnych działań w celu jej pokonania. Takie zadaniowe podejście do własnej choroby może wspierać nadzieje na uzyskanie korzyści osobistych i materialnych (Janowski i in., 2009).

Kolejny czynnik socjodemograficzny, tj. stan cywilny, również okazał się nieistotny dla oceny znaczenia własnej choroby przez pacjentów z SMRR i z cukrzycą typu 2. To ustalenie koresponduje z wynikami uzyskanymi już podczas prac normalizacyjnych dotyczących skali służącej do oceny znaczenia własnej choroby, kiedy to nie stwierdzono istotnych różnic w tym zakresie (Janowski i in., 2009). Jednakże pozostawanie w związku małżeńskim/partnerskim jest dość powszechnie uznawane za wskaźnik wsparcia społecznego i predyktor odporności na trudy życia (Knoll i Schwarzer, 2012). Być może w przypadku osób z chorobami przewlekłymi, szczególnie z postępującymi i nieuleczalnymi jak SM, perspektywa niemożności określenia długofalowych celów życiowych, obawy z powodu stygmatyzującej niesprawności ruchowej, somatycznej i seksualnej oraz malejące szanse na zajmowanie się dziećmi czy wnukami hamują tendencję do obciążania współmałżonka/partnera negatywnymi refleksjami. Także z troski o drugą osobę i jej zdrowie przewlekle chorzy starają się ukrywać swoje przeżycia związane z poczuciem straty i krzywdy oraz piętnującymi ograniczeniami w sferze osobistej, zawodowej i rodzinnej (Bereza, 2009). 
Przeprowadzone badanie wykazało, że osoby chorujące na SMRR oraz posiadające wykształcenie licencjackie i wyższe rzadziej ujmują swą chorobę jako korzyść, krzywdę bądź nieszczęście stanowiące niezasłużoną karę aniżeli osoby z wykształceniem zawodowym i średnim. Podobne ustalenia dotyczą chorych z cukrzycą typu 2, ponieważ osoby z wykształceniem licencjackim i wyższym rzadziej traktują swą chorobę jako zagrożenie, krzywdę czy korzyść niż osoby z wykształceniem podstawowym, zawodowym i średnim. Wyższy poziom wykształcenia i (z założenia) wiedzy na temat choroby może minimalizować towarzyszące jej negatywne emocje i uczucia, a tym samym regulować poczucie napiętnowania, zwłaszcza w odniesieniu do osób nastawionych na aktywne poszukiwanie informacji (Miller, 1989, za: Janowski, 2006; Taylor, 1983). Badania przeprowadzone wśród pacjentów z różnymi schorzeniami wykazały, że osoby lepiej wykształcone rzadziej oceniają swą chorobę jako zagrożenie (Janowski, 2006), jako powód stygmatyzujących ograniczeń psychofizycznych czy też jako źródło korzyści (Janowski i in., 2009).

Podsumowując, należy stwierdzić, że hipoteza dotycząca zależności między czynnikami socjodemograficznymi a oceną znaczenia własnej choroby przez pacjentów z SMRR i z cukrzycą typu 2 została pozytywnie zweryfikowana w odniesieniu do wykształcenia. Płeć i stan cywilny okazały się nieistotnym źródłem zmienności.

Druga hipoteza dotyczyła różnic pomiędzy badanymi grupami chorych w zakresie oceny znaczenia własnej choroby. Ta hipoteza została zweryfikowana pozytywnie w odniesieniu do kategorii doświadczania choroby jako przeszkody/straty, co wskazuje na traktowanie jej przez osoby z SMRR jako nieusuwalnej przyczyny dotkliwych i stygmatyzujących ograniczeń psychofizycznych oraz rezygnacji z osobistych, rodzinnych i zawodowych celów, planów czy marzeń. Tak oceniana choroba jest niedającym się zapomnieć utrudnieniem, które stale i boleśnie zawęża granice niezależności osobistej, samorealizacji, kontaktów z innymi ludźmi czy rozwoju zawodowego. Pogłębiona analiza wykazała, że porównywane grupy pacjentów podobną miarę przykładają do negatywnego znaczenia i zagrożenia ze strony swoich chorób, co jest zrozumiałe ze względu na ich przewlekły charakter. Największe różnice międzygrupowe dotyczyły przykładania przez pacjentów z SMRR o wiele większej wagi do oceny choroby jako negatywnego wydarzenia życiowego oraz jako wyraźnie ich piętnującej przeszkody/straty i krzywdy. Natomiast chorzy na cukrzycę typu 2 przypisali wyższą wartość przeważnie pozytywnie nacechowanym ocenom znaczenia własnej choroby, jak korzyść, wyzwanie i wartość. 
Ostatnio coraz częściej zwraca się uwagę na rolę subiektywnej oceny znaczenia choroby w procesie emocjonalnej i behawioralnej adaptacji do trudnej sytuacji życiowej (Bishop, 2000; Janowski, Tatala, Jedynak, Księżpolska i Głowacka, 2016; Kossakowska, 2007; Sęk, 2012; Sęk i Cieślak, 2012). Ponadto podkreśla się rolę posiadanych zasobów osobistych oraz zasobów zewnętrznych, do których należy przede wszystkim wsparcie społeczne (Ford, Barrow i Stohl, 1996, za: Janowski i in., 2016; Juczyński, 1999; Sęk, 2012). Indywidualne zróżnicowanie tych czynników powoduje, że ta sama choroba może u jednych osób wywoływać kompletną dezorganizację życia, u innych zaś nie uruchamiać poważniejszych zmian. Takie podejście skłania do sporządzenia próby typologii osób przewlekle chorych ze względu na kryterium oceny znaczenia własnej choroby.

Można więc przyjąć, że - niezależnie od rodzaju przewlekłej choroby - pacjenci trudniej adaptujący się do niej, częściej niż pacjenci łatwiej przystosowujący się do choroby, oceniają ją jako zagrożenie, przeszkodę/ stratę i krzywdę oraz nadają jej negatywne, stygmatyzujące znaczenie. Ocena choroby w takich kategoriach powoduje pogorszenie funkcjonowania psychospołecznego, gdyż zostaje utożsamiona z poważną przeszkodą wymagającą rezygnacji z dotychczasowych celów i planów. Choroba budzi lęk, niepokój, wstyd, poczucie winy, niesprawiedliwości i krzywdy, prowadząc do spadku samooceny i poczucia własnej wartości, do zaburzeń depresyjnych i wyczerpania (Dennison, Moss-Morris i Chadler, 2009; Jopson i Moss-Morris, 2003; Telford, Kralik i Koch, 2006). Może jednak być także traktowana jako pretekst do ucieczki przed innymi problemami oraz jako powód do zaspokojenia potrzeby zainteresowania, troski, opieki czy zabezpieczenia materialnego (Janowski i in., 2009). Słabemu nastawieniu przystosowawczemu towarzyszy poczucie napiętnowania i bycia gorszym, bezradność, pesymizm, apatia i skłonność do wycofywania się z relacji społecznych, co z kolei wpływa na wybór nieefektywnych strategii radzenia sobie ze stresującą sytuacją choroby przewlekłej (Bandura, 2007; Rzepa, Żaba i Silny, 2011).

Pacjenci łatwiej adaptujący się do choroby traktują ją jako bolesne wydarzenie życiowe o charakterze wyzwania, które wzbudza lęk i świadomość ograniczeń w codziennym funkcjonowaniu, ale jednocześnie uruchamia motywację do odrzucenia strategii biernego poddania się losowi, a tym samym motywuje do pokonywania trudności spowodowanych chorobą. Źródłem motywacji jest najczęściej przekonanie o zdolności radzenia sobie w sytuacjach trudnych i dotychczasowe doświadczenia dowodzące osiągania wytyczonych celów. Tak zmotywowane osoby umieją dostrzec pozytywne aspekty choroby oraz potrafią ocenić ją jako pewną wartość. 
Wtedy doświadczanie cierpienia związanego z chorobą zyskuje głębszy sens, często trudny do zrozumienia nawet przez osoby najbliższe. Jeśli choroba jest postrzegana w pozytywnych kategoriach, to zazwyczaj dochodzi do zmiany nastawienia przystosowawczego i przewartościowania własnego życia (Andruszkiewicz, Kubica, Nowik, Marzec i Banaszkiewicz, 2014; Chodkiewicz, 2004; Janowski i in., 2009; Kościelak, 2010; Ziarko, 2014).

Nadawanie określonego znaczenia własnej chorobie to bardzo ważny krok w procesie adaptacji do niej, wyznaczający określoną postawę wobec choroby i jej leczenia oraz uruchamiający strategie radzenia sobie z konsekwencjami trudnej sytuacji życiowej (Schussler, 1992; Steuden, 2002; Watkins i in., 2000). Dlatego ocena znaczenia, jakie chorzy nadają swojej chorobie, powinna być poważnie traktowanym wskaźnikiem ukierunkowującym opiekę medyczną i psychologiczną na poprawę jakości życia pacjentów.

Na podstawie przeprowadzonego badania można sformułować następujące wnioski.

1. Choroba przewlekła jest odbierana jako ważne i negatywne wydarzenie życiowe zarówno przez chorych na SMRR, jak i na cukrzycę typu 2.

2. Spośród podstawowych czynników socjodemograficznych wykształcenie jest powiązane z oceną znaczenia własnej choroby. Im niższy poziom wykształcenia, tym częściej jawi się ona jako krzywda i źródło korzyści w ocenie pacjentów z SMRR i cukrzycą typu 2, a w przypadku chorych z cukrzycą typu 2 również jako zagrożenie.

3. Oceny znaczenia obu chorób w kategoriach zagrożenia są podobne wśród chorych na SMRR i cukrzycę typu 2. Chorzy na SMRR natomiast o wiele częściej niż chorzy na cukrzycę typu 2 oceniają swoją chorobę jako przeszkodę/stratę, tj. nieusuwalną i stygmatyzującą przyczynę ograniczeń psychofizycznych i rezygnacji z osobistych, rodzinnych i zawodowych celów, planów czy marzeń.

4. Ocena znaczenia własnej choroby umożliwia podział pacjentów na trudniej i łatwiej adaptujących się do choroby przewlekłej. Do pierwszego typu należą osoby oceniające chorobę w kategoriach negatywnych, tj.: zagrożenia, przeszkody/straty i krzywdy. Pacjenci lepiej przystosowani nadają zaś chorobie pozytywne znaczenie, traktując ją jako wyzwanie, wartość i korzyść, co motywuje ich do zmiany dotychczasowego stylu życia.

5. Diagnostyczna ocena znaczenia choroby wyznacza kierunek i zasady postępowania z pacjentami, zwłaszcza gdy zasadniczym celem zespołów diagnostyczno-terapeutycznych jest poprawa jakości życia osób przewlekle chorych. 


\section{Literatura}

Andruszkiewicz, A., Kubica, A., Nowik, M., Marzec, A., Banaszkiewicz, M. (2014). Poczucie koherencji i poczucie własnej skuteczności jako wyznaczniki akceptacji choroby w grupie pacjentów przewlekle chorych. Problemy Pielęgniarstwa, 22 (2), 239-245.

Bandura, A. (2007). Teoria społecznego uczenia się. Warszawa: Wydawnictwo Naukowe PWN.

Bereza, B. (2009). Doświadczanie własnej choroby przez pacjentów dializowanych. Lublin: Wydawnictwo Towarzystwa Naukowego KUL.

Bishop, G. (2000). Psychologia zdrowia. Wrocław: Astrum.

Böhm, D., Stock, G. S., Bangemann, K., Snitjer, I., Werfel, T., Weyergraf, A., Schulz, W., Jäger, B., Schmidt-Ott, G. (2013). Perceived relationships between severity of psoriasis symptoms, gender, stigmatization and quality of life. Journal of the European Academy of Dermatology and Venereology, 23, 220-226.

Brzozowska, E., Talarska, D. (2001). Poziom satysfakcji z życia u chorych na stwardnienie rozsiane. Pielęgniarstwo Polskie, 2 (12), 275-283.

Chodkiewicz, J. (2004). Problem akceptacji choroby u osób uzależnionych od alkoholu: znaczenie zasobów osobistych. Acta Universitatis Lodziensis. Folia Psychologica, 8, 123-133.

Chojnacka-Szawłowska, G. (2012). Psychologiczne aspekty przewlekłych chorób somatycznych. Warszawa: Vizja Press \& IT.

Czupryniak, L., Strojek, K. (2016). Diabetologia. Gdańsk: Via Medica.

Dennison, L., Moss-Morris, R., Chalder, T. (2009). A review of psychological correlates of adjustment in patients with multiple sclerosis. Clinical Psychology Review, 29, 141-53.

Dolińska-Zygmunt, G. (2001). Uwarunkowania zachowania się wobec własnej choroby. W: G. Dolińska-Zygmunt (red.), Podstawy psychologii zdrowia (ss. 243-252). Wrocław: Wydawnictwo Uniwersytetu Wrocławskiego.

Goffman, E. (2005). Piętno. Gdańsk: Gdańskie Wydawnictwo Psychologiczne.

Gupta, M. A., Gupta, A. K. (1995). Age and gender differences in the impact of psoriasis on quality of life. International Journal of Dermatology, 34 (10), 700-703.

Heszen-Klemens, I. (1979). Poznawcze uwarunkowania zachowania się wobec własnej choroby. Wrocław: Zakład Narodowy im. Ossolińskich, Wydawnictwo Polskiej Akademii Nauk.

Janowski, K. (2006). Osobowościowe uwarunkowania radzenia sobie ze stresem łuszczycy. Lublin: POLIHYMNIA.

Janowski, K., Steuden, S., Kuryłowicz, J., Nieśpiałowska-Steuden, M. (2009). The Diseaserelated appraisals scale: a tool to measure subjective perception of the disease situation. W: K. Janowski, S. Steuden (red.), Biopsychosocial Aspects of Health and Disease (ss. 108-125). Lublin: CPPP Scientific Press.

Janowski, K., Tatala, M., Jedynak, T., Księżpolska, A., Głowacka, B. (2016). Wsparcie społeczne a ocena własnej choroby, nasilenie objawów depresyjnych i akceptacja życia z chorobą u kobiet po mastektomii. Polskie Forum Psychologiczne, 21 (2), 188-205.

Jopson, N. M., Moss-Morris, R. (2003). The role of illness severity and illness representations in adjusting to multiple sclerosis. Journal of Psychosomatic Research, 54, 503-511. 
Juczyński, Z. (1999). Narzędzia pomiaru w psychologii zdrowia. Przegląd Psychologiczny, 42 (4), 43-56.

Karakiewicz, B., Stala, C., Grochans, E., Rotter, I., Mroczek, B., Zaremba-Pechmann, L., Laszczyńska, M., Giezek, M. (2010). Ocena wpływu wybranych czynników socjodemograficznych na jakość życia osób chorujących na stwardnienie rozsiane. Roczniki Pomorskiej Akademii Medycznej w Szczecinie, 56 (3), 107-112.

Keltikangas-Jarvinen, L. (1986). Psychological meaning of illness and coping with disease. Psychotherapy and Psychosomatics, 45, 84-90.

Klupa, T. (2010). Leczenie niefarmakologiczne i edukacja pacjenta z cukrzycą. W: D. Moczulski (red.), Diabetologia (ss. 56-63). Warszawa: Medical Tribune Polska.

Knoll, N., Schwarzer, R. (2012). Prawdziwych przyjaciół... Wsparcie społeczne, stres, choroba i śmierć. W: H. Sęk, R. Cieślak (red.), Wsparcie społeczne, stres i zdrowie (ss. 29-48). Warszawa: Wydawnictwo Naukowe PWN.

Koligat, D., Leszczyński, P., Pawlak-Buś, K., Koligat, A., Zaprutko, T., Kus, K., Paczkowska, A., Ratajczak, P., Nowakowska, E. (2012). Wpływ chorób przewlekłych (osteoporozy i cukrzycy) na health related quality-of-life - badanie pilotażowe. Nowiny Lekarskie, 28 (2), 122-128.

Kossakowska, M. (2007). Wybrane psychospołeczne uwarunkowania jakości życia w stwardnieniu rozsianym (SM). Psychologia Jakości Życia, 6 (2), 167-187.

Kościelak, R. (2010). Poczucie umiejscowienia kontroli i przekonania o własnej skuteczności w zdrowiu i chorobie. Kraków: Oficyna Wydawnicza Impuls.

Król, J., Koziarska, D., Rzepa, T., Szcześniak, M., Nowacki, P. (2017). Self-perception of illness among patients with Relapsing-Remitting Multiple Sclerosis (RRMS) - preliminary report. Postępy Psychiatrii i Neurologii, 26 (1), 24-35.

Lazarus, R., Folkman, S. (1984). Stress, Appraisal and Coping. New York: Springer.

Lazarus, R. S. (1966). Psychological Stress and the Coping Process. New York: McGraw-Hill.

Lipowski, Z. J. (1970). Physical illness, the individual, and the coping process. Psychiatry in Medicine, 1, 91-102.

Maciejak, Z., Wawrzyniak, S. (2013). Objawy kliniczne i przebieg choroby. W: J. Losy (red.), Stwardnienie rozsiane (ss. 59-74). Lublin: Wydawnictwo Czelej.

Majda, A., Józefowska, H. (2009). Zasoby osobiste pacjentów z przewlekłą obturacyjną chorobą płuc. Problemy Pielęgniarstwa, 17 (4), 283-293.

Michałowska-Wieczorek, I. (2006). Rola wsparcia w zmaganiu się z chorobą nowotworową. Psychoonkologia, 10 (2), 51-56.

Moczulski, D. (2010). Obraz kliniczny cukrzycy. W: D. Moczulski (red.), Diabetologia (ss. 8-13). Warszawa: Medical Tribune Polska.

Rzepa, T., Jakubowicz, O., Witmanowski, H., Żaba, R. (2013). Disease-induced level of shame in patients with acne, psoriasis and syphilis. Postępy Dermatologii i Alergologii, 30 (4), 233-236.

Rzepa, T., Stanišić, M. G. (2012). Attitude towards one’s illness vs. attitude towards a surgical operation, displayed by patients diagnosed with asymptomatic abdominal aortic aneurysm and asymptomatic internal carotid artery stenosis. International Angiology, 31 (4), 376-385.

Rzepa, T., Żaba, R., Jakubowicz, O. (2014). Wstyd doświadczany z powodu własnej choroby a satysfakcja życiowa. Czasopismo Psychologiczne, 20 (1), 111-118. 
Rzepa, T., Żaba, R., Jakubowicz, O., Szramka-Pawlak, B. (2013). Emocje i obawy doświadczane w związku z poważną chorobą a ocena własnej sytuacji życiowej i pozycji społecznej. Dermatologia Kliniczna, 15 (1), 10-16.

Rzepa, T., Żaba, R., Silny, W. (2011). Management of the stressful stigma attached to sexually transmitted disease (preliminary report). Ginekologia Polska, 82, 675-679.

Sak, J. (2013). Wielowymiarowość postrzegania choroby w kontekście przekonań zdrowotnych i poczucia sensu życia: rozprawa habilitacyjna. Lublin: Uniwersytet Medyczny w Lublinie.

Schmid-Ott, G., Jäger, B., Kuensbeck, H. W., Ott, R., Lamprecht, F. (1996). Dimensions of stigmatization in patients with psoriasis in a „Questionnaire on Experience with Skin Complaints”. Dermatology, 193, 304-310.

Schussler, G. (1992). Coping strategies and individual meanings of illness. Social Science and Medicine, 34, 427-432.

Sęk, H. (2012). Rola wsparcia życiowego w sytuacjach stresu życiowego. W: H. Sęk, R. Cieślak (red.), Wsparcie społeczne, stres i zdrowie (ss. 49-67). Warszawa: Wydawnictwo Naukowe PWN.

Sęk, H., Cieślak, R. (2012). Wsparcie społeczne - sposoby definiowania, rodzaje i źródła wsparcia, wybrane koncepcje teoretyczne. W: H. Sęk, R. Cieślak (red.), Wsparcie spoteczne, stres i zdrowie (ss. 11-28). Warszawa: Wydawnictwo Naukowe PWN.

Steuden S. (2002). Z psychologicznej problematyki zdrowia i choroby. W: P. Oleś, S. Steuden, J. Toczydłowski (red.), Jak świata mniej widzę. Zaburzenia widzenia a jakość życia (ss. 27-36). Lublin: Towarzystwo Naukowe KUL.

Szramka-Pawlak, B., Dańczak-Pazdrowska, A., Rzepa, T., Szewczyk, A., Sadowska-Przytocka, A., Żaba, R. (2013). Health-related quality of life, optimism, and coping strategies in persons suffering from localized scleroderma. Psychology, Health \& Medicine, 18 (6), 654-663.

Taylor, S. E. (1983). Adjustment to threatening events: A theory of cognitive adaptation. American Psychologist, 38, 1161-1173.

Telford, K., Kralik, D., Koch, T. (2006). Acceptance and denial: implications for people adapting to chronic illness: literature review. Journal of Advanced Nursing, 55 (4), 457-464.

Toombs, S. K. (2003). The Meaning of Illness. A Phenomenological Account of the Different Perspectives of Physician and Patient. Dordrecht: Kluwer Academic Publishers.

Watkins, K. W., Connell, C. M., Fitzgerald, J. T., Klem, L., Hickey, T., Ingersoll-Dayton, B. (2000). Effects of adults' self-regulation on quality of life outcomes. Diabetes Care, 23, 1511-1515.

Wender, M., Liberski, P. P. (2013). Neuropatologia. W: J. Losy (red.), Stwardnienie rozsiane (ss. 29-44). Lublin: Wydawnictwo Czelej.

Zaborski, J. (2010). Psychologiczne następstwa zaburzeń seksualnych w stwardnieniu rozsianym. W: A. Potemkowski (red.), Psychologiczne aspekty stwardnienia rozsianego (ss. 103-112). Poznań: Termedia.

Zdrowie i zachowanie zdrowotne mieszkańców Polski w świetle Europejskiego Ankietowego Badania Zdrowia (EHIS) 2014 (2015). Warszawa: GUS.

Ziarko, M. (2014). Zmaganie się ze stresem choroby przewlekłej. Poznań: Wydawnictwo Naukowe Wydziału Nauk Społecznych UAM. 
